\title{
Long-term Productivity of Three Rambutan Cultivars Grown in an Ultisol Soil in Puerto Rico
}

\author{
Ricardo Goenaga ${ }^{1}$
}

AdDitionAL INDEX wORDs. Nephelium lappaceum, yield, fruit number

\begin{abstract}
SUMMARY. The globalization of the economy, increased ethnic diversity, and a greater demand for healthy and more diverse food production has increased the demand for tropical fruit, including rambutan (Nephelium lappaceum). Replicated field trials to evaluate performance of rambutan cultivars have been very limited and as with many other tropical fruit crops, there is a scarcity of information on best management practices and optimal growing conditions for rambutan. The objective of this study was to determine the yield potential of three rambutan cultivars (Jitlee, $\mathrm{R}-134, \mathrm{R}-162$ ) when the age of grafted trees was $\approx 20$ years. The data were compared with that obtained from an early production period when the age of the trees was $\approx 10$ years. This information may help rambutan growers make expansion and/or investment plans. Number of fruit and yield in 2017 were significantly higher in 2017 than in 2016. In 2017, average fruit number and yield of cultivars were 582,774 fruit/ha and $19,528 \mathrm{~kg} \cdot \mathrm{ha}^{-1}$, respectively, whereas in 2016 were $394,269 \mathrm{fruit} / \mathrm{ha}$ and $13,164 \mathrm{~kg} \cdot \mathrm{ha}^{-1}$, respectively. There were no significant differences among cultivars for number of fruit produced, averaging 488,521 fruit/ha. This production is higher than the 5-year average obtained from the 2005-09 harvest period when grafted trees were about 9 years old. The results of this study demonstrate that grafted rambutan trees can remain prolific in mature orchards.
\end{abstract}

$\mathrm{R}$

ambutan is a member of the soapberry (Sapindaceae) family and along with other important fruit crops such as lychee (Litchee chinensis) and longan (Dimocarpus longan) is native to southeast Asia (Tindall, 1994). The edible portion of the rambutan fruit is a fleshy, translucent white sarcotesta, which arises from an integument surrounding a single oblong seed. The fruit are non-climacteric with little change in total soluble solids or titratable acidity after harvest (O'Hare, 1995). Currently, Thailand is the leading producer of rambutan worldwide (Dinh, 2016; Zee et al., 1998); however, Indonesia, Malaysia, Australia, and some countries in the Western Hemisphere also produce this fruit commercially. The globalization of the

U.S. Department of Agriculture, Agricultural Research Service, Tropical Agriculture Research Station, 2200 P.A. Campos Avenue, Suite 201, Mayaguez, PR 00680-5470

I thank Jose Luis Rodriguez for his excellent field assistance and to Heber Irizarry for reviewing this manuscript.

Mention of trade names or commercial products in this publication is solely for the purpose of providing specific information and does not imply recommendation or endorsement of the U.S. Department of Agriculture.

${ }^{1}$ Corresponding author. E-mail: Ricardo.Goenaga@ ars.usda.gov.

https://doi.org/10.21273/HORTTECH04181-18 economy, increased ethnic diversity, and a greater demand for healthy and more diverse food production has increased the demand for tropical fruit, including rambutan. Formal replicated field trials to evaluate performance of rambutan cultivars have been limited. There is a scarcity of information on best management practices and optimal growing conditions. Field and greenhouse studies have demonstrated that rambutan is highly tolerant to acid soils (Goenaga, 2011; Pérez-Almodovar and Goenaga, 2015). In a study lasting 10 years ( 5 years of fruit production), Goenaga and Jenkins (2011) found considerable genetic diversity among rambutan cultivars for economically important traits such as fruit production, yield, total soluble solids, and fruit characteristics, among others.
Erratic fruit production or "offyears" are typical in many tropical fruit crops (Goenaga and Jenkins, 2012; Goenaga et al., 2016). Wheelwright (1986) reported a wide yearto-year variability for fruit production among populations of 22 species in the laurel (Lauraceae) family. During a 7 -year evaluation period, he found that overall fruit production was high during 3 nonconsecutive years and low during 4 years. Longer-term studies of orchards are needed to provide answers to critical production questions. Before recommending a particular cultivar to fruit growers it is therefore essential to carry out longterm research to assess the sustainability of crop productivity. Currently, few researchers working in fruit improvement programs in public and private institutions have the resources to carry such research.

The objective of this study was to determine the long-term productivity of three rambutan cultivars in an 18 year-old orchard.

\section{Materials and methods}

The experimental data were obtained from an experimental site established on Sept. 1999 at the Corozal Agricultural Experiment Station of the University of Puerto Rico (Goenaga and Jenkins, 2011) to evaluate eight rambutan cultivars for yield and fruit quality traits. The soil is an Ultisol (Corozal clay: clayey, mixed, isohyperthermic Aquic Haplohumults) typical of the humid tropics. After the termination of the 5 -year evaluation experiment in 2009 , the orchard continued receiving intensive management until most of the trees were destroyed by the $155-\mathrm{mph}$ winds brought by Hurricane Maria on 20 Sept. 2017. Until that date, fertilization was provided every 3 months using a $15 \mathrm{~N}-2.2 \mathrm{P}-$ $16.3 \mathrm{~K}-1.8 \mathrm{Mg}$ commercial mixture at a rate of $240 \mathrm{lb} /$ acre. Irrigation was

\begin{tabular}{llll}
\hline $\begin{array}{l}\text { Units } \\
\begin{array}{l}\text { To convert U.S. to SI, } \\
\text { multiply by }\end{array}\end{array}$ & U.S. unit & SI unit & $\begin{array}{l}\text { To convert SI to U.S., } \\
\text { multiply by }\end{array}$ \\
\hline 0.4047 & acre(s) & $\mathrm{ha}$ & 2.4711 \\
0.3048 & $\mathrm{ft}$ & $\mathrm{m}$ & 3.2808 \\
3.7854 & $\mathrm{gal}$ & $\mathrm{L}$ & 0.2642 \\
2.54 & inch $(\mathrm{es})$ & $\mathrm{cm}$ & 0.3937 \\
25.4 & inch $(\mathrm{es})$ & $\mathrm{mm}$ & 0.0394 \\
1.1209 & $\mathrm{lb} / \mathrm{acre}$ & $\mathrm{kg} \cdot \mathrm{ha}^{-1}$ & 0.8922 \\
1.6093 & $\mathrm{mph}$ & $\mathrm{km} \cdot \mathrm{h}^{-1}$ & 0.6214 \\
1 & $\mathrm{ppm}$ & $\mathrm{mg} \cdot \mathrm{kg}^{-1}$ & 1 \\
6.8948 & $\mathrm{psi}$ & $\mathrm{kPa}$ & 0.1450 \\
$\left({ }^{\circ} \mathrm{F}-32\right) \div 1.8$ & ${ }^{\circ} \mathrm{F}$ & ${ }^{\circ} \mathrm{C}$ & $\left({ }^{\circ} \mathrm{C} \times 1.8\right)+32$ \\
& & &
\end{tabular}

Hortlechnology · December 2018 28(6) 
provided with spinner jets (model DXMAG368X; Maxijet, Dundee, FL) spaced $20 \mathrm{ft}$ apart and providing 13.5 $\mathrm{gal} / \mathrm{h}$ at $20 \mathrm{psi}$ when the soil water tension at a depth of $30 \mathrm{~cm}$ exceeded $50 \mathrm{kPa}$. Weeds within the planting rows were suppressed with strip applications of herbicide (glyphosate). Weeds between rows were controlled with a tractor mower. Spray oil emulsion fungicide (Saf-T-Side; Brandt Consolidated, Springfield, IL) was occasionally used during rainy season to control sooty mold.

During the growing years 2010 to 2015 the experimental orchard was harvested similarly as in the evaluation trial (Goenaga and Jenkins, 2011), but cultivar yield data on many fruit traits were not recorded due to shortage in hand labor.

Because of lack of information and concern about the long-term productivity of grafted rambutan trees, the author resumed recording fruit production in 2016 from three selected cultivars: Jitlee, R-134, and $\mathrm{R}-162$. These cultivars were selected for the study because they showed consistent high production of fruit and high yield during 2005-09 at the Corozal Agricultural Experiment Station (Goenaga and Jenkins, 2011). These cultivars were grafted onto ' $\mathrm{R}$ 167' rambutan rootstocks. Trees were arranged in a randomized complete block design with three replications. Within a replication, plots for each cultivar contained three trees spaced $20 \mathrm{ft}$ apart and $20 \mathrm{ft}$ between adjacent rows in a triangular array. Representative fruit from each cultivar are shown in Fig. 1. The experimental area was surrounded by two guard rows of 'R-134' seedlings.

Before initiating data recording in 2016, soil samples were taken 2 months before initiation of the experiment by taking borings at a depth of 0 to $25 \mathrm{~cm}$ from each of the tree rows. Samples were air-dried and passed through a 16-mesh screen. The soil has a $\mathrm{pH}$ of $5.71,38.5 \mathrm{mg} \cdot \mathrm{kg}^{-1}$ ammoniumnitrogen $\left(\mathrm{NH}_{4}-\mathrm{N}\right), 17.7 \mathrm{mg} \cdot \mathrm{kg}^{-1}$ nitrate- $\mathrm{N}\left(\mathrm{NO}_{3}-\mathrm{N}\right), 12.1 \mathrm{mg} \cdot \mathrm{kg}^{-1}$ phosphorous (P), $468 \mathrm{mg} \cdot \mathrm{kg}^{-1}$ potassium $(\mathrm{K}), 2513 \mathrm{mg} \cdot \mathrm{kg}^{-1}$ calcium $(\mathrm{Ca})$, $158 \mathrm{mg} \cdot \mathrm{kg}^{-1}$ magnesium $(\mathrm{Mg}), 127$ $\mathrm{mg} \cdot \mathrm{kg}^{-1}$ iron (Fe), $81 \mathrm{mg} \cdot \mathrm{kg}^{-1}$ manganese $(\mathrm{Mn}), 6.1 \mathrm{mg} \cdot \mathrm{kg}^{-1}$ zinc $(\mathrm{Zn})$, $99 \mathrm{mg} \cdot \mathrm{kg}^{-1}$ aluminum (Al), and $1.5 \%$ organic carbon. The 63-year mean annual rainfall is $1832 \mathrm{~mm}$ and Class A pan evaporation is $1320 \mathrm{~mm}$. Mean
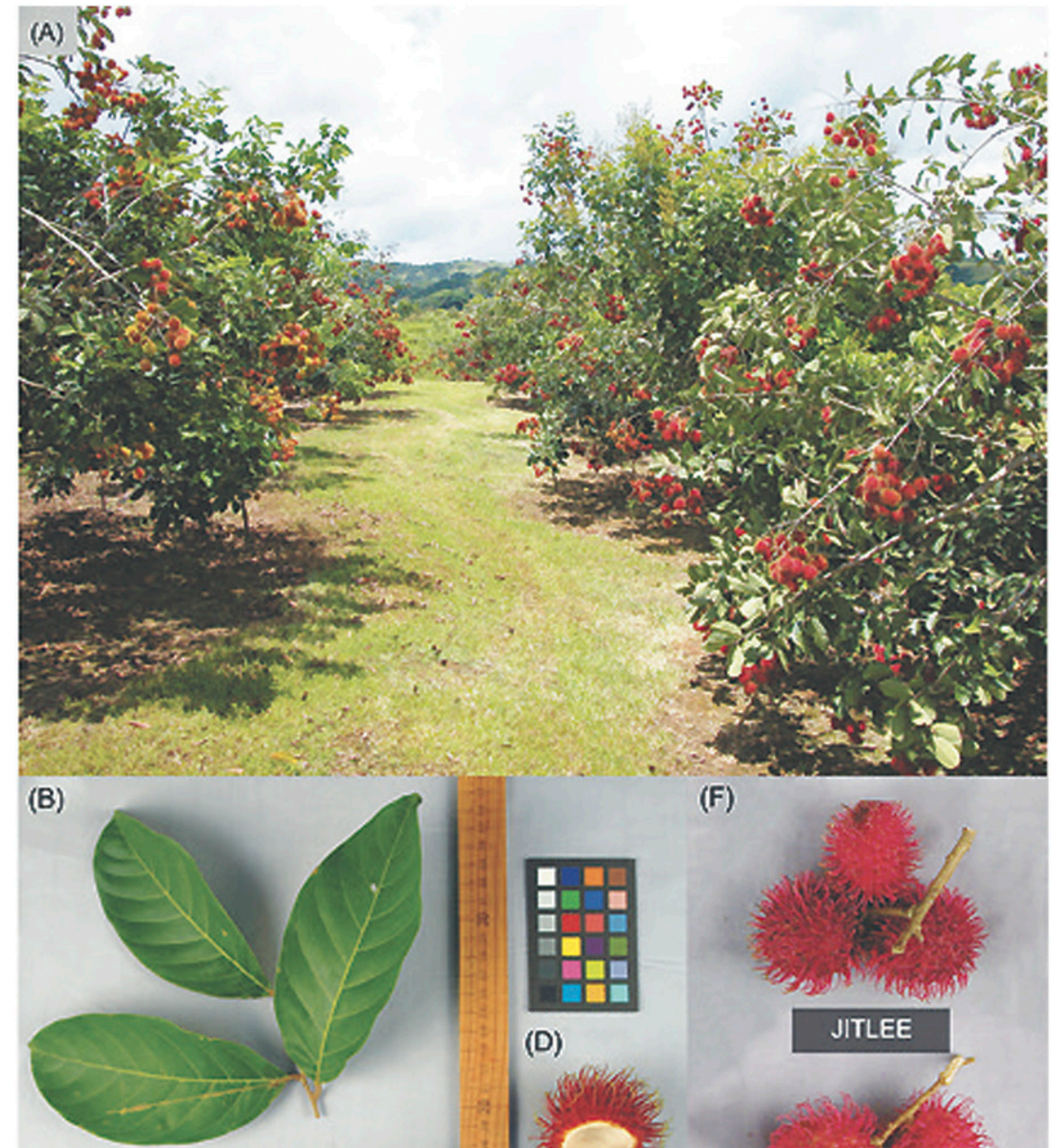

(F)
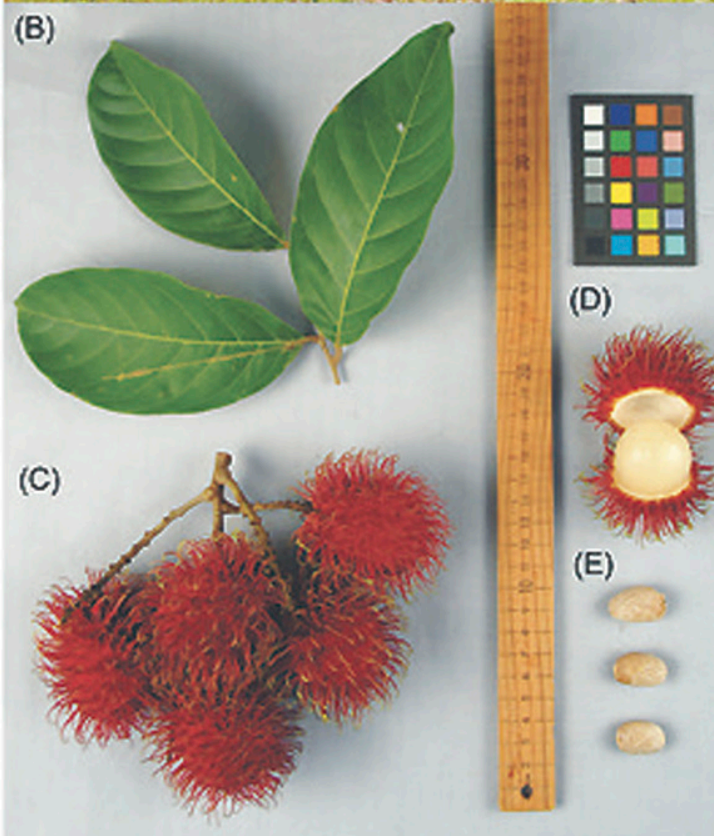

(D)

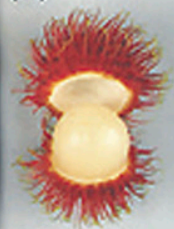

(E)

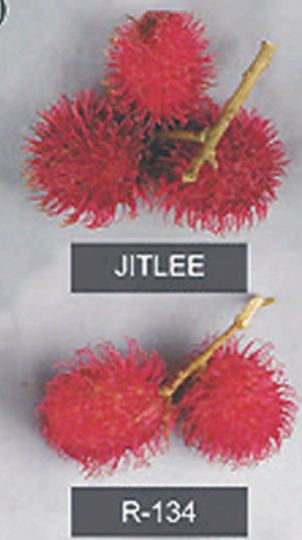

R-134

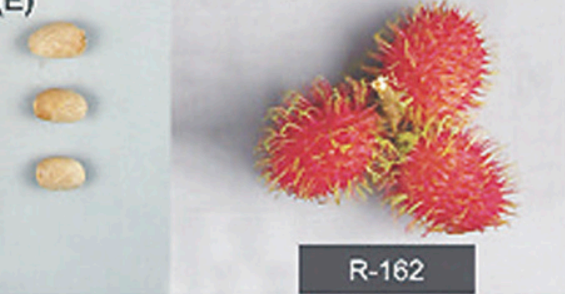

Fig. 1. Rambutan orchard, fruit components and cultivar differences: (A) experimental orchard in production, (B) leaves, (C) fruit cluster, (D) opened fruit with pulp (aril) exposed, (E) seeds, and (F) fruit clusters of cultivars used in the experiment; $1 \mathrm{~cm}=0.3937$ inch .

monthly maximum and minimum temperatures are 29.8 and $19.5^{\circ} \mathrm{C}$. Samples were air-dried and passed through a 16-mesh screen. Soil pH in water and $0.01 \mathrm{M}$ calcium chloride (1 soil : 2 water) were measured with a glass electrode. Phosphorous and exchangeable cations $(\mathrm{K}, \mathrm{Mg}$, and Ca) were extracted with Mehlich III solution [extract is composed of $0.2 \mathrm{M}$ acetic acid, $0.25 \mathrm{M}$ ammonium nitrate, $0.015 \mathrm{~m}$ ammonium fluoride,
$0.013 \mathrm{M}$ nitric acid, and $0.001 \mathrm{M}$ ethylene diamine tetraacetic acid (EDTA) (Amacher, 2007)] and determined by inductively coupled plasma (ICP) spectrometry (Sumner and Miller, 2007). Organic carbon was determined by the Walkley-Black method (Nelson and Sommers, 2007). Soil ammonium and nitrate were determined by steam distillation (Mulvaney, 2007).

During the 2016-17 harvest period, fruit clusters from the three 
selected cultivars were harvested from three of the five replications in the original study (Goenaga and Jenkins, 2011). Harvests were initiated in $\mathrm{Au}-$ gust of each year. At harvest, telescopic long reach pruners (model 160ZR-3.0-5; ARS, Osaka, Japan) were used to cut fruit clusters on terminal ends of the branches from each of the three trees per replication and cultivar. The weight of fruit clusters attached to stem pieces was recorded in the field (fruit cluster yield). Fruit clusters were then brought to the laboratory where they were separated from stems, counted, and weighed again (fruit yield). Fruit from each tree were then composited by replication and cultivar. Flowering both years occurred during midMarch and fruit harvested from $\mathrm{Au}^{-}$ gust to January; weekly harvests were made during the harvesting period. On the basis of trees in flower and immature fruit, it was estimated that $\approx 20 \%$ of the potential crop was lost in 2017 as a result of the hurricane. The original plan was to at least obtain yield data for 3 successive years, 201618. However, the arrival of Hurricane Maria shortened the evaluation period.

Analysis of variance was carried out using the GLM procedure of SAS (version 9.4 for Windows; SAS Institute, Cary, NC). After significant $\mathrm{F}$ test at $P<0.05$, mean separation was performed with the Tukey's honestly significant difference range test.

\section{Results and discussion}

Years showed a significant effect $(P<0.01)$ on average number of fruit and yield per hectare (Table 1). Cultivar had a significant effect on fruit yield but not fruit number. The cultivar $\times$ year interaction was not significant for yield parameters (Table 1 ).

Despite the experimental area being hit by a powerful hurricane, fruit number and yield were significantly higher in 2017 than in 2016. In 2017, average fruit number and yield of cultivars were 582,774 fruit/ ha and $19,528 \mathrm{~kg} \cdot \mathrm{ha}^{-1}$, respectively, whereas in 2016, they were 394,269 fruit/ha and 13,164 kg.ha- ${ }^{-1}$, respectively. Erratic production patterns characterized by relatively low production during 1 or 2 successive years following heavy cropping has been reported in mature rambutan trees. For example, Goenaga and Jenkins (2011) found that number of fruit and fruit yield in cultivar R-162 respectively declined by $15 \%$ and $17 \%$ from 2007 to 2008 and then increased by $37 \%$ and $27 \%$, respectively, in 2009. Similarly, cultivar R-134 showed a $7 \%$ decline in fruit production in 2007, leveled off in 2008, and then had a $33 \%$ increase in fruit production in 2009. The possibility of water stress impeding flower initiation or development in 2016 was ruled out because supplemental irrigation was supplied when necessary. Retention of mature fruit on trees is sometimes practiced [e.g., avocado (Persea americana)] to obtain premium market prices. However, this practice can drive the tree into a biennial cropping cycle (Schaffer and Andersen, 1994). In this experiment, fruit were harvested periodically and was not a factor in inducing biennial cropping. Wheelwright (1986) proposed that in trees of laurel family, annual variation in fruit production results from a combination of life-history trade-offs, such as previous reproductive efforts, vegetative growth competing with reproductive growth, responses to climatic variation, and changes in pollinator abundance and behavior. In this study, high fruit load before 2016 most probably resulted in depletion of assimilates, which then caused an "off-year" because of light blooming as trees built up carbohydrate reserves (Scholefield et al., 1985; Stander and Cronje, 2016). Biennial production is not always characterized by an every-otheryear cycle. An "on-year" can be followed by one or more "off-years" and vice versa (Paz-Vega, 1997).

There were no significant differences among cultivars for number of fruit produced, averaging 488,521 fruit/ha (Table 1). This figure is higher than the 5-year average obtained for harvest period 2005 to 2009 for 6.5 to 10.5-year-old trees of the same cultivars (Goenaga and Jenkins, 2011). Considering that $\approx 20 \%$ of the 2017 crop was lost as a result of hurricane damage and the discovery of new fungal diseases associated with rambutan production in Puerto Rico (Rossman et al., 2007, 2010; Serrato-Diaz et al., 2011, 2012), the potential fruit production during the 2016-17 harvest period would have been even higher than that of the earlier production period, 200509 (Goenaga and Jenkins, 2011).

Cultivar Jitlee had significantly higher fruit yield per hectare than R-

Table 1. Number of fruit, fruit cluster yield, and fruit yield of three rambutan cultivars evaluated in Puerto Rico during two harvest periods. ${ }^{\mathrm{z}}$

\begin{tabular}{|c|c|c|c|c|c|c|}
\hline \multirow[b]{2}{*}{ Cultivar } & \multicolumn{3}{|c|}{$2-y r$ avg (2016-17) } & \multicolumn{3}{|c|}{$5-y r$ avg $(2005-09)^{y}$} \\
\hline & $\begin{array}{c}\text { Fruit } \\
(\text { no./ha })^{\mathrm{x}}\end{array}$ & $\begin{array}{c}\text { Fruit } \\
\text { cluster } \\
\text { yield } \\
\left(\mathrm{kg} \cdot \mathrm{ha}^{-1}\right)^{\mathrm{x}}\end{array}$ & $\begin{array}{c}\text { Fruit yield } \\
\left(\mathrm{kg}^{\left.\mathrm{h} \mathrm{ha}^{-1}\right)}\right.\end{array}$ & $\begin{array}{c}\text { Fruit } \\
\text { (no./ha) }\end{array}$ & $\begin{array}{c}\text { Fruit } \\
\text { cluster } \\
\text { yield } \\
\left(\mathrm{kg} \cdot \mathrm{ha}^{-1}\right)\end{array}$ & $\begin{array}{c}\begin{array}{c}\text { Fruit } \\
\text { yield } \\
\left(\mathrm{kg} \cdot \mathrm{ha}^{-1}\right)\end{array} \\
\end{array}$ \\
\hline Jitlee & 577,722 & 23,023 & 21,035 & 453,850 & 16,462 & 15,171 \\
\hline $\mathrm{R}-134$ & 458,625 & 15,221 & 13,979 & 448,670 & 16,210 & 14,873 \\
\hline $\operatorname{HSD}(0.05)^{\mathrm{w}}$ & 206,299 & 7,575 & 7,022 & & & \\
\hline Year $(\mathrm{Y})$ & ** & ** & & & & \\
\hline Cultivar (C) & ns & * & * & & & \\
\hline $\mathrm{Y} \times \mathrm{C}$ & ns & ns & ns & & & \\
\hline
\end{tabular}

${ }^{\mathrm{z}}$ Values are means of three replications and 2 years $(2016-17)$.

yalues obtained from Goenaga and Jenkins (2011).

${ }^{\mathrm{x}} \mathrm{l}$ fruit $/ \mathrm{ha}=0.4047$ fruit $/$ acre; $\mathrm{l} \mathrm{kg} \cdot \mathrm{ha}^{-1}=0.8922 \mathrm{lb} /$ acre.

w Tukey's honest significant difference test at $P=0.05$.

Ns, * ${ }^{* *}$ Nonsignificant or significant at $P \leq 0.05$ or 0.01 , respectively. 
134, but it did not differ statistically from the yield obtained by R-162 (Table 1). As with number of fruit, average yield of cultivars Jitlee and R$162\left(17,529 \mathrm{~kg} \cdot \mathrm{ha}^{-1}\right)$ was higher in the 2016-17 evaluation period than the 5year average obtained from 2005-09 (Goenaga and Jenkins, 2011). An even higher yield increase would also have resulted if the same assumption of a $20 \%$ potential crop loss is taken into consideration for these two cultivars.

Although rambutan fruit are normally sold as individual units packed in plastic clamshells in groups of 8-10 fruit, the fruit is also sold in clusters in farmers' markets. In this instance, the fruit remains attached to small stem sections after harvest. In this study, it was found that on average, about $8 \%$ of the harvested clusters were composed of stem pieces (Table 1). This is the same percentage as that found by Goenaga and Jenkins (2011) during the 2005-09 harvest period. Marketing fruit in clusters has the advantage of being less laborious and minimizing fruit damage because detaching stems from fruit may cause rupturing of the skin. However, because of bulkiness, marketing fruit as clusters make it unsuitable for packrefrigerated to reduce moisture loss of fruit and increase shelf life. Moisture loss through fruit spinterns can be significant. Studies have shown that, after storing rambutan for $6 \mathrm{~d}$ at an ambient temperature of $27^{\circ} \mathrm{C}$, the fruit lost $45 \%$ in weight as compared with $29 \%$ when stored at $10{ }^{\circ} \mathrm{C}$. When fruit was stored for the same period in perforated bags at $10{ }^{\circ} \mathrm{C}$, weight loss was only $2.8 \%$ (Mendoza et al., 1972). If relative humidity is kept at $95 \%$ and fruit at $7-10{ }^{\circ} \mathrm{C}$, rambutan have a storage life of $\approx 10-15 \mathrm{~d}$ (O'Hare, 1995). Therefore, marketing rambutan in fruit clusters is not conducive to prolonged shelf life.

In conclusion, this study is the first to report long-term performance of rambutan cultivars almost 20 years after field establishment of an experimental orchard. Fruit production averaged 488,521 fruit/ha, which is higher than average production previously obtained from the same, younger trees during the harvest period 2005-09. These results demonstrate that rambutan production can remain prolific in mature orchards. aging in clamshells. Clamshells can be

\section{Literature cited}

Amacher, M.C. 2007. Nickel, cadmium and lead, p. 739-768. In: D.L. Sparks (ed.). Methods of soil analysis. Part 3. Chemical methods. Soil Sci. Soc. Amer., Amer. Soc. Agron. Madison, WI.

Dinh, H.H. 2016. Nephelium lappaceum, rambutan tree. 16 July 2018. <https:// www.worldwidefruits.com/nepheliumlappaceum-rambutan.html>.

Goenaga, R. 2011. Dry matter production and leaf elemental concentrations of rambutan grown on an acid Ultisol. J. Plant Nutr. 34:753-761.

Goenaga, R. and D.A. Jenkins. 2011. Yield and fruit quality traits of rambutan cultivars grafted onto a common rootstock and grown at two locations in Puerto Rico. HortTechnology 21:136-140.

Goenaga, R. and D.A. Jenkins. 2012. Yield and fruit quality traits of mamey sapote cultivars grown at two locations in Puerto Rico. HortTechnology 22:263-267.

Goenaga, R., D. Jenkins, and A. Marrero. 2016. Yield performance of six lychee cultivars grown at two locations in Puerto Rico. HortTechnology 26:748-753.

Mendoza, D.B., E.R.B. Pantastico, and F.B. Javier. 1972. Storage and handling of rambutan (Nephelium lappaceum L.). Philippines Agr. 55:322-332.

Mulvaney, R.L. 2007. Nitrogen: Inorganic forms, p. 1123-1184. In: D.L. Sparks (ed.). Methods of soil analysis. Part 3. Chemical methods. Soil Sci. Soc. Amer., Amer. Soc. Agron., Madison, WI.

Nelson, D.W. and L.E. Sommers. 2007. Total carbon, organic carbon and organic matter, p. 961-1010. In: D.L. Sparks (ed.). Methods of soil analysis. Part 3. Chemical methods. Soil Sci. Soc. Amer., Amer. Soc. Agron., Madison, WI.

O’Hare, T.J. 1995. Postharvest physiology and storage of rambutan. Postharvest Biol. Technol. 6:189-199.

Paz-Vega, S. 1997. Alternate bearing in the avocado (Persea americana Mill.), p. 117-148. California Avocado Soc. 1997 Yrbk. 81, San Juan Capistrano, CA.

Pérez-Almodovar, D. and R. Goenaga. 2015. Influence of aluminum on growth, mineral nutrition and organic acid exudation of rambutan (Nephelium lappaceum). Expt. Agr. 51:582-593.

Rossman, A.Y., R. Goenaga, and L. Keith. 2007. First report of Dolabra nepheliae on rambutan and litchi in Hawaii and Puerto Rico. Plant Dis. 91:1685.

Rossman, A.Y., C.L. Schoch, D.F. Farr, K. Nishijima, L. Keith, and R. Goenaga. 2010. Dolabra nepheliae on rambutan and lychee represents a novel lineage of phytopathogenic Eurotiomycetes. Mycoscience 51:300-309.

Schaffer, B. and P.C. Andersen. 1994. Miscellaneous tropical fruits, p. 3-37. In: B. Schaffer and P.C. Andersen (eds.). Handbook of environmental physiology of fruit crops: II. Subtropical and tropical crops. CRC Press, Boca Raton, FL.

Scholefield, P.B., M. Sedgley, and D.McE. Alexander. 1985. Carbohydrate cycling in relation to shoot growth, floral initiation and development and yield in the avocado. Scientia Hort. 25:99-110.

Serrato-Diaz, L.M., L.I. Rivera-Vargas, R. Goenaga, G.J.M. Verkley, and R.D. French-Monar. 2011. First report of Lasmenia sp. causing rachis necrosis, flower abortion, fruit rot and leaf spots on rambutan in Puerto Rico. Plant Dis. 95:1313.

Serrato-Diaz, L.M., E.I. Latoni-Brailowsky, L.I. Rivera-Vargas, R. Goenaga, and R.D. French-Monar. 2012. First report of Gliocephalotrichum bulbilium and G. simplex causing fruit rot of rambutan in Puerto Rico. Plant Dis. 96:1225.

Stander, O.P.J. and P.J.R. Cronje. 2016. Reviewing the commercial potential of hand thinning in citrus with a cost-benefit analysis of summer hand thinning of 'Nadorcott' mandarin. HortTechnology 26:206-212.

Sumner, M.E. and W.P. Miller. 2007. Cation exchange capacity and exchange coefficients, p. 1201-1230. In: D.L. Sparks (ed.). Methods of soil analysis. Part 3. Chemical methods. Soil Sci. Soc. Amer., Amer. Soc. Agron. Madison, WI.

Tindall, H.D. 1994. Rambutan cultivation. FAO Plant Production Protection Paper 121. Food and Agriculture Organization of the United Nations, Rome, Italy.

Wheelwright, N.T. 1986. A seven-year study of individual variation in fruit production in tropical bird-dispersed tree species in the family Lauraceae, p. 19-36. In A. Estrada and T.H. Fleming (eds.). Frugivores and seed dispersal. Dr. W. Junk Publishers. Dordrecht, The Netherlands.

Zee, F.T.P., H.T. Chan, and C.R. Yen. 1998. Lychee, longan, rambutan and pulasan, p. 290-335. In: P.E. Shaw, H.T. Chan, and S. Nagy (eds.). Tropical and subtropical fruits. AgScience, Auburndale, FL. 